\title{
Effect of vitamin D supplementation, and interaction with vitamin D receptor genotype, on biochemical markers of bone turnover in adults aged $20->64$ years
}

\author{
K. Seamans ${ }^{1}$, A. J. Lucey ${ }^{1}$, T. R. Hill ${ }^{1}$, S. Muldowney ${ }^{1}$, J. M. W. Wallace ${ }^{3}$, G. Horigan $^{3}$, \\ M. S. Barnes ${ }^{3}$, M. Kiely ${ }^{1}$ and K. D. Cashman ${ }^{1,2}$ \\ ${ }^{1}$ Departments of Food \& Nutritional Sciences and ${ }^{2}$ Medicine, University College Cork, Cork, Republic of Ireland \\ and ${ }^{3}$ Northern Ireland Centre for Food and Health, University of Ulster, Coleraine BT52 1SA, UK
}

Vitamin D plays a central role in bone metabolism and mineralization across all age-groups ${ }^{(1)}$. While there has been a lot of research interest in the effect of vitamin D on bone health variables in early and later life, to date there has only been limited investigation of the effect of vitamin $\mathrm{D}$ supplementation on bone metabolism in young adults ${ }^{(2,3)}$, despite the fact that there is potential for gain in bone mass in young adults for about 10 years after longitudinal bone growth has stopped ${ }^{(1)}$.

The effect of vitamin D supplementation $(0,5,10$ and $15 \mu \mathrm{g}$ cholecalciferol/d) on serum 25-hydroxyvitamin $\mathrm{D}(25(\mathrm{OH}) \mathrm{D})$, parathyroid hormone (PTH), osteocalcin (OC), bone-specific alkaline phosphatase (BAP), carboxy-terminal collagen cross-links (CTx) and aminoterminal collagen cross-links (NTx) concentrations was investigated in a randomised placebo-controlled double-blind intervention study in men and women aged 20->64 years (n 203) over 22 weeks during winter 2006- $7^{(4)}$ in Cork and Coleraine. Fasting serum levels of these markers were measured by ELISA at baseline and end point. Subjects were genotyped for Fok I and Taq I restriction fragment length polymorphisms in the vitamin D receptor (VDR) gene using real-time PCR.

ANOVA showed no baseline differences in any markers of $\mathrm{Ca}$ or bone metabolism between the four treatment groups. ANOVA showed that while there was a significant dose-related response in serum $25(\mathrm{OH}) \mathrm{D}$ with vitamin $\mathrm{D}$ supplementation, the change $(\Delta)$ in other biomarkers of $\mathrm{Ca}$ and bone metabolism from pre- to post intervention was unaffected by vitamin $\mathrm{D}$ supplementation in these $20-40$-yearold adults (data for $>64$ year olds not shown).

\begin{tabular}{|c|c|c|c|c|c|c|c|c|c|}
\hline \multirow[b]{3}{*}{ Treatment group ... } & & & \multicolumn{6}{|c|}{ Cholecalciferol $(\mu \mathrm{g} / \mathrm{d})$} & \multirow[b]{3}{*}{$P$} \\
\hline & \multicolumn{2}{|c|}{ Placebo $(n$ 57) } & \multicolumn{2}{|c|}{$5(n 48)$} & \multicolumn{2}{|c|}{$10(n 57)$} & \multicolumn{2}{|c|}{$15(n 53)$} & \\
\hline & Mean & SD & Mean & SD & Mean & SD & Mean & $\mathrm{SD}$ & \\
\hline$\left.\Delta \mathrm{s} 25(\mathrm{OH}) \mathrm{D}(\mathrm{nmol} / \mathrm{l})^{4}\right)$ & $-35.0^{\mathrm{a}}$ & 22.8 & $-17.8^{\mathrm{b}}$ & 20.6 & $-15.2^{\mathrm{c}}$ & 22.9 & $-7.1^{\mathrm{d}}$ & 32.2 & $<0.001$ \\
\hline$\Delta \mathrm{s}$ PTH $(\mathrm{ng} / \mathrm{ml})$ & 7.9 & 18.1 & 2.4 & 20.4 & 5.9 & 15.0 & 5.3 & 15.2 & 0.434 \\
\hline$\Delta \mathrm{s}$ OC $(\mathrm{ng} / \mathrm{ml})$ & -0.4 & 1.6 & -0.4 & 1.6 & 0.0 & 2.0 & -0.3 & 2.3 & 0.615 \\
\hline$\Delta \mathrm{s}$ BAP $(\mathrm{U} / \mathrm{l})$ & 0.4 & 5.0 & -0.2 & 4.7 & 1.3 & 6.5 & -0.9 & 5.8 & 0.191 \\
\hline$\Delta \mathrm{s}$ CTx $(\mathrm{mmol} / \mathrm{l})^{*}$ & 0.04 & $-0.07-1.08$ & 0.03 & $-0.01-1.08$ & 0.02 & $-0.05-1.18$ & 0.02 & $-0.08-0.08$ & 0.579 \\
\hline$\Delta \mathrm{s}$ NTx $(\mathrm{mmol} / \mathrm{l})$ & -0.5 & 3.0 & 0.3 & 4.2 & -0.3 & 2.7 & -0.8 & 3.2 & 0.397 \\
\hline
\end{tabular}

$\mathrm{S}$, serum. *Values are medians and interquartile ranges.

The results were unaltered when analysis of covariance (ANCOVA) was used to account for possible confounding effects of research centre, age, gender and baseline concentrations. ANCOVA also showed that there was no significant interaction between treatment group and Fok I or Taq I VDR genotype in relation to any of the markers.

In conclusion, vitamin D supplementation had no effect on biochemical markers of bone turnover in apparently-healthy 20-40-year-old adults and $>64$ year olds, even when stratified by VDR genotype.

We wish to acknowledge the UK Food Standards Agency and the Irish Department of Agriculture, Food \& Fisheries through the Food Institutional Research Measure for their support.

1. Institute of Medicine (1997) Dietary Reference Intakes for Calcium, Phosphorus, Magnesium, Vitamin D, and Fluoride. Washington, DC: National Academy Press.

2. Barnes MS, Robson PJ, Bonham MP et al. (2006) Eur J Clin Nutr 60, 727-733.

3. Meier C, Woitge HW, Witte K et al. (2004) J Bone Miner Res 19, 1221-1230.

4. Cashman KD, Hill TR, Lucey AJ et al. (2008) Am J Clin Nutr 88, 1535-1542. 